\title{
EFFECT OF IRRIGATION INTERVALS AND DEFOLIANT APPLICATION ON YIELD AND FIBER QUALITY OF GIZA 92 COTTON VARIETY
}

\author{
(Received:6.11.2013)
}

\author{
By \\ S.E. D. Elayan , A. A. Abo-El-Dahab , A.S. Arafa* and A. I. Mahmoud* \\ Department. of Agronomy, Faculty of Agriculture, Cairo University ,Giza \\ * Cotton Research Institute, Agriculture Research Center, Giza, Egypt
}

\begin{abstract}
Two field experiments were conducted at Sakha Station, Cotton Research Institute, Agricultural Research Center, during 2010 and 2011 seasons, to investigate the impact of irrigation interval, defoliant type and defoliation time on the yield, yield components and fiber properties of the Egyptian cotton $(G$. barbadense, L.) variety Giza 92 . Split Split plot design with four replicates was used. The irrigation intervals (I) occupied the main plots as follows:( $\left.\mathrm{I}_{1}\right)$ normal irrigation ( at two- week interval), normal irrigation (at two week interval) until flowering then increasing time to 4 week interval $\left(\mathrm{I}_{2}\right)$, and four week interval $\left(\mathrm{I}_{3}\right)$. The second factor defoliant type (D) occupied the sub-plots with three levels: "Dropp" defoliant- $\left(\mathrm{D}_{1}\right)$, "Prep" defoliant - $\left(\mathrm{D}_{2}\right)$, and control spraying with water- $\left(\mathrm{D}_{3}\right)$. The third factor, time of defoliant application $(\mathrm{T})$ was distributed randomly in the sub-sub plots as follows: defoliant spray after $60 \%$ of bolls open $\left(\mathrm{T}_{1}\right)$, spraying after $70 \%$ of bolls open $\left(\mathrm{T}_{2}\right)$,spraying after $80 \%$ of bolls are open $\left(\mathrm{T}_{3}\right)$. The effects of all main factors were significant in both seasons except for the effect of spraying date on the no. of fruiting branches. The significance of the interaction varied according to the cotton trait. The results revealed that the best irrigation treatment is the 15- days interval throughout the growing season. The "Dropp" defoliant generally surpassed the "Prep" defoliant in affecting all characters under study. The application of defoliant after $60 \%$ of bolls are open resulted in the highest value of all traits under study except the number of fruiting branches in both seasons. It was concluded that normal irrigation coupled with the application of the defoliant "Dropp" after $60 \%$ of bolls are open had a positive effect on the cotton agronomic traits, cotton yield and cotton fiber characteristics .
\end{abstract}

Key words:cotton, defoliation, irrigation interval.

\section{INTRODUCTION}

Defoliation is defined as the application of chemicals to encourage or force cotton leaves to drop from the plant in order to facilitate harvesting. Defoliation function is a balancing act between killing the leaves and not affecting the leaves (Baker et al., 1987). Deciding when to defoliate is a complicated matter because crop maturity, crop condition, current and expected weather conditions and harvest scheduling must be considered (Edmisten ,2006). Phipps et al., (2002) found that delayed defoliation may increase boll rotting or decrease lint and fiber quality due to weathering. Yield may also be reduced, therefore defoliation decisions are a compromise between late season yield gains, timely harvest and defoliant rate (Snipes and Baskin, (1999) and Faircloth et al. (2004) noted that maturity was reached 10 to 15 days earlier due to chemical defoliation. Proper timing and rate of defoliation can significantly increase yield as well as micronaire and other fiber quality traits (Robertson et al., 2003). In contrast, Kelley et al. (2000) and Gwathmey and Wyatt (2001) indicated that premature defoliation before $60 \%$ of bolls open may decrease yields and fiber quality. However, Fromme et al. (2005) concluded that chemical defoliants such as "Dropp" at 0.45 $\mathrm{kg} / \mathrm{ha}$ insignificantly affect lint percentage, fiber length, fiber strength and length uniformity ratio. Defoliation is useful when cotton plants face some stresses like drought and high temperature. Also, water stress especially during fruiting stage adversely affected yield and fiber quality (Silvertooth and Galadima 2003 and Zaxos et al., 2012) while,( Jill et al., 2006 and Cetin et al.,2011) indicated that variable rate irrigation affected fiber lint yield and quality. Fiber quality parameters of interest are micronaire value, fiber strength, and fiber length properties. In 2001 and 
2003, micronaire value was not affected by the rate of irrigation. Fiber strength improved with a decrease in water application in 2001, but was not affected in 2003.

\section{MATERIALS AND METHODS}

Two field experiments were carried out at Sakha Experimental Station, Cotton Research Institute. Cotton seeds were sown on April 10 and April 7 in 2010 and 2011 seasons, respectively. The experimental unit included 6 ridges (3 meters long and $60 \mathrm{~cm}$ wide) representing an area of $10.8 \mathrm{~m}^{2}$. Hills were $20 \mathrm{~cm}$ apart within the row and seedlings were thinned to 2 plants/hill. Standard agricultural practices were followed throughout the growing season. The objective of the present study was to investigate the effect of irrigation intervals, defoliant types and defoliation time on lint yield, yield components and fiber properties of the Egyptian cotton (G.barbadense, L.) variety Giza 92 which represents the extra long stable cotton category. The split split plot design with four replicates was used. The time of irrigation (I) occupied the main plots as follows:

1 - $\mathrm{I}_{1}$ : normal irrigation every 15 days (two - week interval) .

2- $\mathrm{I}_{2}$ : normal irrigation (two - week interval) until flowering, followed by irrigation every 4 weeks.

3- $\mathrm{I}_{3}$ : irrigation every four - week interval .

The second factor, defoliant type (D) occupied the sub - plots as follows:

1- $\mathrm{D}_{1}:$ :"Dropp"defoliant(N-phenyl-N1,2,3thiadiawol -5-yl-Urea) 50\%w.p

2- $\mathrm{D}_{2}$ :",Prep"defoliant( Sodium cis-2chloroacrylate).

3- $\mathrm{D}_{3}$ : Control spraying with water .

The third factor, spraying date of defoliant $(\mathrm{T})$ was distributed randomly in the sub-sub plots, as follows:

$1-\mathrm{T}_{1}$ : spraying after $60 \%$ of bolls are open .

2- $\mathrm{T}_{2}$ : spraying after $70 \%$ of bolls are open

$3-\mathrm{T}_{3}$ : spraying after $80 \%$ of bolls are open.

Dropp was used at the rate of $30 \mathrm{~g} / \mathrm{fed}$, and

Prep solution was used at $600 \mathrm{~cm}^{3} / \mathrm{fed}$.

The LSD test at the .0 .05 level was used to test the significance of differences among treatment means. Data were subjected to the analysis of variance according to the methods described by Snedecor and Cochran (1982).

The characters were

1-Yield and yield components: at harvest, ten plants were randomly selected from the inner ridges of each sub-plot to measure the following attributes: no. of sympodial branches per plant, no. of open bolls /plant, average boll weight (g.), cotton yield /plant $(\mathrm{g})$, lint percentage ratio of lint weight to seed cotton weight in the sample expressed as percentage, (lint weight $\times 100$ )/seed cotton weight), and seed cotton yield /fed. (Kentar.).

\section{2- Fiber properties}

Micronaire value was measured using Micromate instrument according to (ASTM, D3818,1986). While,The HVI instrument system was used to determine fiber upper half mean (mm), fiber strength $(\mathrm{g} / \mathrm{tex})$ according to (ASTM: D- 4605 -1986.

\section{RESULTS AND DISCUSSION \\ 3.1. Agronomic attributes \\ 3.1.1. Number of sympodial branches}

Data pertaining to the number of sympodial branches of Giza 92 variety under the applied treatments in the two Experimental seasons are given in Tables (1,2 and 3). Results show that the effects of irrigation interval and defoliant type were significant in both seasons. In contrast, the defoliant application time, as well as the first and second order interactions were not significant in both seasons. As to the effect of irrigation interval, normal irrigation every 15 days resulted in the highest number of sympodial branches (14.37 and 13.99) in both seasons. This may be due to that plants exposed to water stress seem to end the growth cycle which negatively affect the no. of sympodial branches. Similar results were reported by Silvertooth and Galadima (2003). As to the sub-main factor (defoliant type), the "Prep" defoliant caused the highest number of sympodial branches (12.66 and 12.51 in 2010 and 2011seasons, respectively).

\subsubsection{Number of open bolls /plant}

Data in Tables (1, 2 and 3,) show the effect of irrigation interval, defoliant type and spraying time on the no. of open bolls /plant. It is clear that the effects of these main factors were significant in both seasons, while the significance of the first and the second order interactions varied between seasons. As for the effect of irrigation treatments, normal irrigation exhibited the largest means of open bolls /plant (11.87 and 11.47) due to sufficient water available to the plants at the physiological stage. This decreased shedding and enhanced normal plant growth and increased plant productivity. Results pertaining to defoliant types revealed that the highest numbers of open bolls (13.87and 12.65) was obtained from Dropp. As to the effect of spraying date, the greatest numbers (13.01and 11.97) were obtained from 
Table(1): The effect of irrigation intervals, defoliant type, and spraying date on no. of sympodia branches, no. of open boll and boll weight for Giza 92 variety in 2010 and 2011 seasons.

\begin{tabular}{|c|l|l|l|l|l|l|l|}
\hline \multicolumn{2}{|c|}{ Main effects } & \multicolumn{2}{c|}{$\begin{array}{c}\text { No. sympodia } \\
\text { branches }\end{array}$} & \multicolumn{2}{c|}{$\begin{array}{c}\text { No. of open } \\
\text { bolls }\end{array}$} & \multicolumn{2}{c|}{$\begin{array}{c}\text { Boll weight } \\
\text { (g.) }\end{array}$} \\
\hline & & $\mathbf{2 0 1 0}$ & $\mathbf{2 0 1 1}$ & $\mathbf{2 0 1 0}$ & $\mathbf{2 0 1 1}$ & $\mathbf{2 0 1 0}$ & $\mathbf{2 0 1 1}$ \\
\hline & $\mathbf{I}^{\mathbf{1}}$ & 14.37 & 13.99 & 11.87 & 11.47 & 3.49 & 3.46 \\
$\begin{array}{c}\text { Irrigation } \\
\text { intervals }\end{array}$ & $\mathbf{I}^{\mathbf{2}}$ & 11.83 & 11.70 & 12.78 & 11.50 & 3.05 & 3.04 \\
\hline L.S.D 0.05 & $\mathbf{I}^{\mathbf{3}}$ & 10.97 & 10.85 & 13.16 & 11.86 & 2.68 & 2.65 \\
\hline \multirow{3}{*}{ Defoliant } & & 0.28 & 0.46 & 0.13 & 0.15 & 0.02 & 0.04 \\
\hline L.S.D 0.05 & $\mathbf{D}^{\mathbf{1}}$ & 12.66 & 12.51 & 13.87 & 12.65 & 3.11 & 3.08 \\
\hline \multirow{2}{*}{ Spraying } & $\mathbf{D}^{\mathbf{2}}$ & 12.59 & 12.23 & 12.95 & 12.01 & 3.08 & 3.07 \\
date & $\mathbf{D}^{\mathbf{3}}$ & 11.91 & 11.81 & 10.99 & 10.17 & 3.02 & 3.00 \\
\hline & & 0.54 & 0.58 & 0.28 & 0.22 & 0.02 & 0.02 \\
\hline L.S.D 0.05 & $\mathbf{T}^{\mathbf{1}}$ & 12.87 & 12.59 & 13.01 & 11.97 & 3.11 & 3.10 \\
& $\mathbf{T}^{\mathbf{2}}$ & 12.34 & 12.17 & 12.60 & 11.62 & 3.07 & 3.04 \\
\hline
\end{tabular}

Table (2):Effect of the first order interaction between irrigation intervals, defoliant type, and spraying date on, no. of sympodia, no.of open boll and boll weight for Giza 92 variety in $2010 \& 2011$.

\begin{tabular}{|c|c|c|c|c|c|c|c|c|}
\hline \multirow{2}{*}{\multicolumn{3}{|c|}{$\begin{array}{l}\text { Character } \\
\text { Treatment } \\
\end{array}$}} & \multicolumn{2}{|c|}{$\begin{array}{c}\text { No. sympodia } \\
\text { branches }\end{array}$} & \multicolumn{2}{|c|}{$\begin{array}{c}\text { No. of open } \\
\text { bolls }\end{array}$} & \multicolumn{2}{|c|}{$\begin{array}{c}\text { Boll weight } \\
\text { (g.) }\end{array}$} \\
\hline & & & 2010 & 2011 & 2010 & 2011 & 2010 & 2011 \\
\hline \multirow{9}{*}{.0. } & & $\mathbf{D}^{1}$ & 14.91 & 14.32 & 14.03 & 12.93 & 3.53 & 3.49 \\
\hline & $\mathbf{I}^{1}$ & $\mathbf{D}^{2}$ & 14.79 & 14.23 & 11.92 & 11.82 & 3.48 & 3.47 \\
\hline & & $\mathbf{D}^{3}$ & 13.42 & 13.43 & 9.65 & 9.64 & 3.43 & 3.42 \\
\hline & & $\mathbf{D}^{1}$ & 11.88 & 11.96 & 13.58 & 12.21 & 3.07 & 3.06 \\
\hline & $\mathbf{I}^{2}$ & $\mathbf{D}^{2}$ & 11.82 & 11.62 & 13.30 & 12.08 & 3.07 & 3.06 \\
\hline & & $\mathbf{D}^{\mathbf{3}}$ & 11.78 & 11.53 & 11.47 & 10.21 & 3.01 & 3.00 \\
\hline & & $\mathbf{D}^{1}$ & 11.20 & 11.24 & 13.99 & 12.79 & 2.74 & 2.70 \\
\hline & $\mathbf{I}^{3}$ & $\mathbf{D}^{2}$ & 11.16 & 10.84 & 13.63 & 12.14 & 2.70 & 2.70 \\
\hline & & $\mathbf{D}^{3}$ & 10.54 & 10.47 & 11.84 & 10.66 & 2.61 & 2.60 \\
\hline \multirow{9}{*}{ 包 } & & $T^{1}$ & 14.73 & 14.28 & 12.38 & 11.89 & 3.53 & 3.52 \\
\hline & $\mathbf{I}^{1}$ & $\mathbf{T}^{2}$ & 14.43 & 14.02 & 11.72 & 11.45 & 3.47 & 3.44 \\
\hline & & $\mathbf{T}^{3}$ & 13.93 & 13.69 & 11.51 & 11.06 & 3.45 & 3.42 \\
\hline & & $\mathbf{T}^{\mathbf{1}}$ & 12.47 & 12.37 & 13.15 & 11.79 & 3.07 & 3.08 \\
\hline & $\mathbf{I}^{2}$ & $\mathbf{T}^{2}$ & 11.70 & 11.60 & 12.84 & 11.54 & 3.05 & 3.04 \\
\hline & & $\mathbf{T}^{3}$ & 11.30 & 11.14 & 12.34 & 11.17 & 3.03 & 3.01 \\
\hline & & $\mathbf{T}^{1}$ & 11.42 & 11.13 & 13.50 & 12.25 & 2.73 & 2.72 \\
\hline & $\mathbf{I}^{3}$ & $\mathbf{T}^{2}$ & 10.89 & 10.91 & 13.26 & 11.87 & 2.71 & 2.66 \\
\hline & & $\mathbf{T}^{3}$ & 10.59 & 10.51 & 12.71 & 11.48 & 2.61 & 2.58 \\
\hline \multirow{9}{*}{ 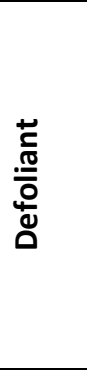 } & & $\mathbf{T}^{1}$ & 13.26 & 12.74 & 14.40 & 13.08 & 3.16 & 3.16 \\
\hline & $D^{1}$ & $\mathbf{T}^{2}$ & 12.59 & 12.54 & 13.84 & 12.69 & 3.11 & 3.07 \\
\hline & & $\mathbf{T}^{3}$ & 12.13 & 12.23 & 13.35 & 12.17 & 3.07 & 3.01 \\
\hline & & $\mathbf{T}^{\mathbf{1}}$ & 12.95 & 12.64 & 13.30 & 12.36 & 3.14 & 3.13 \\
\hline & $\mathrm{D}^{2}$ & $\mathbf{T}^{2}$ & 12.47 & 12.14 & 13.02 & 12.07 & 3.08 & 3.05 \\
\hline & & $\mathbf{T}^{3}$ & 12.34 & 11.91 & 12.53 & 11.62 & 3.03 & 3.02 \\
\hline & & $\mathbf{T}^{1}$ & 12.41 & 12.39 & 11.33 & 10.49 & 3.04 & 3.03 \\
\hline & $\mathbf{D}^{3}$ & $\mathbf{T}^{2}$ & 11.97 & 11.84 & 10.96 & 10.10 & 3.03 & 3.01 \\
\hline & & $\mathbf{T}^{3}$ & 11.37 & 11.20 & 10.68 & 9.92 & 2.98 & 2.97 \\
\hline \multirow{3}{*}{ فํㅇ } & \multirow{3}{*}{\multicolumn{2}{|c|}{$\begin{array}{l}\text { ID } \\
\text { IT } \\
\text { DT }\end{array}$}} & $\mathrm{ns}$ & $\mathrm{ns}$ & 0.49 & 0.38 & ns & $\mathrm{ns}$ \\
\hline & & & $\mathrm{ns}$ & ns & 0.56 & ns & ns & 0.04 \\
\hline & & & ns & ns & ns & ns & ns & 0.04 \\
\hline
\end{tabular}


early spraying at $60 \%$ of open bolls in both seasons. In contrast, the lowest values (12.18 and 11.23) were obtained from spraying at $80 \%$ open bolls in both seasons. This may be due to the increase in boll rot and insect attack from late defoliation. This affected the normal growth of the boll and caused large number to remain closed. These results agree with the results obtained by Phipps et al., (2002). The interaction between irrigation interval and the defoliant type, show that the normal irrigation and application of the defoliant "Dropp" resulted in the highest number of open bolls per plant(14.03and 12.93)in the first and second seasons, respectively.

As to the effect of the interaction between irrigation interval and defoliant application date, the highest value (12.38) of open bolls per plant was obtained from "Dropp" defoliant applied after $60 \%$ of bolls open only in 2010 season.

\subsubsection{Boll weight}

Data in Tables (1,2 and 3) show that the effects of the studied main factors were significant in both seasons. However, the first and the second order interaction were not significant in both seasons, except for the interaction between irrigation interval and application date and the interaction between defoliation type and application date in 2011 season only. Concerning the effect of the irrigation treatments, normal irrigation resulted in the heaviest means of boll weight in two seasons (3.49 and $3.46 \mathrm{~g})$ respectively,. In contrast, the four- week interval $\left(\mathrm{I}_{3}\right)$ treatment gave the lowest boll weight $(2.68$ and $2.65 \mathrm{gm}$ ) in both seasons. Results related to the defoliant type revealed that the highest values of boll weight (3.11and $3.08 \mathrm{~g}$ ) were obtained from "Dropp". On the other hand, the lowest boll weights (3.08 and $3.06 \mathrm{~g}$ ) were obtained from the defoliant "Prep" in both seasons, respectively compared to the control. As to the effect of spraying date, the highest boll weight (3.11and $3.10 \mathrm{gm})$ were obtained from early spraying at $60 \%$ open bolls in both seasons. In contrast, the lowest values (3.03and $3.00 \mathrm{~g}$ ) were obtained from spraying at $80 \%$ open bolls in both seasons. This may be due to the fact that late defoliation increased boll rot and insect damage. reduce the boll weight, These results agree with the results obtained by Phipps et al. (2002). As to the effect of the interaction between irrigation interval and application date, the highest boll weight (3.52 g) was obtained when "Dropp" defoliant was applied after the opening of $60 \%$ of bolls in 2011 season. The interaction between the defoliation type and the application date resulted in the highest boll weight $(3.16 \mathrm{~g})$ when "Dropp" defoliant was applied after the opening of $60 \%$ of bolls in 2011 season only. In contrast, the lowest value (3.02 g.) was obtained from the application of "Prep" after $80 \%$ of bolls were open.

\subsubsection{Seed cotton yield/plant}

Results pertaining to the seed cotton yield/plant are presented in Tables (4), and (6). It is obvious that the effects of irrigation interval, defoliant type and spraying time on the seed cotton yield /plant were significant in both seasons, but the significance of the first order interactions varied from season to another. The second-order interaction was not significant in both seasons. Concerning the effect of irrigation treatments, normal irrigation $\left(\mathrm{I}_{1}\right)$ resulted in the highest values of seed cotton yield /plant (32.36 and $31.99 \mathrm{~g}$.) in both seasons, respectively. In contrast, the lowest values (28.98 and $28.70 \mathrm{~g}$.) were obtained from the third irrigation treatment $\left(\mathrm{I}_{3}\right)$.In conclusion, cotton seed yield/plant decreased as the irrigation interval increased, which agrees with the results obtained by Silvertooth and Galadima (2003) ; Zaxos et al. (2012) while, Jill et al .(2006); Cetin et al.(2011). This may be due to the fact that cotton plants irrigated normally are characterized by strong vegetative growth, which results in a great accumulation of the plant dry matter, and enhanced productivity. Regarding the effect of the defoliant type on seed cotton yield /plant, the defoliant "Dropp" surpassed the defoliant "Prep" (32.08 and 31.62g) vs. (31.99 and 30.97g) in both seasons, respectively. Spraying the defoliant after $60 \%$ of open bolls enhanced seed cotton yield /plant (32.41 and 31.73g in 2010 and 2011 seasons, respectively), due to the expected decrease in boll rot and boll damage by weather and insects. The interaction between irrigation and defoliant types, data in Table (5) show that the maximum seed cotton yield /plant (33.84g.) in 2010 season was obtained under normal irrigation using the defoliant "Dropp". The interaction between irrigation treatments and defoliant application date shows that normal irrigation of cotton and spraying the defoliant when $60 \%$ of bolls are open had a good influence on seed cotton yield/plant in 2011season.

\subsubsection{Seed cotton yield /feddan}

Tables $(4,5$ and 6$)$ show that the effects of the irrigation interval, defoliant type and spraying time on seed cotton yield were significant in both seasons. In contrast, the effects of the interactions were not significant in both seasons, except for the 
Table (3): Effects of the second order interactions between irrigation intervals, defoliant type, and spraying date on no. of sympodia, no. of open boll and boll weight for Giza 92 cotton variety in 2010 and 2011 seasons.

\begin{tabular}{|c|c|c|c|c|c|c|c|c|}
\hline \multirow{2}{*}{\multicolumn{3}{|c|}{$\begin{array}{l}\text { Character } \\
\text { Treatment }\end{array}$}} & \multicolumn{2}{|c|}{$\begin{array}{c}\text { No. sympodia } \\
\text { branches }\end{array}$} & \multicolumn{2}{|c|}{$\begin{array}{l}\text { No. of open } \\
\text { bolls }\end{array}$} & \multicolumn{2}{|c|}{$\begin{array}{c}\text { Boll weight } \\
\text { (g.) }\end{array}$} \\
\hline & & & 2010 & 2011 & 2010 & 2011 & 2010 & 2011 \\
\hline \multirow{27}{*}{ 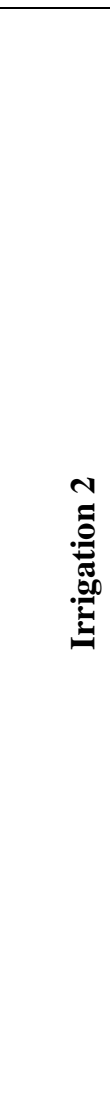 } & \multirow{3}{*}{$\mathbf{D}^{1}$} & $\mathbf{T}^{1}$ & 15.10 & 14.80 & 14.80 & 13.50 & 3.63 & 3.62 \\
\hline & & $\mathbf{T}^{2}$ & 15.00 & 14.33 & 13.73 & 12.87 & 3.50 & 3.43 \\
\hline & & $\mathbf{T}^{3}$ & 14.63 & 13.83 & 13.57 & 12.43 & 3.47 & 3.42 \\
\hline & \multirow{3}{*}{$\mathrm{D}^{2}$} & $\mathbf{T}^{\mathbf{1}}$ & 15.40 & 14.33 & 12.40 & 12.23 & 3.52 & 3.52 \\
\hline & & $\mathbf{T}^{2}$ & 14.63 & 14.20 & 11.77 & 11.90 & 3.47 & 3.46 \\
\hline & & $\mathbf{T}^{3}$ & 14.33 & 14.17 & 11.60 & 11.33 & 3.46 & 3.42 \\
\hline & \multirow{3}{*}{$\mathbf{D}^{3}$} & $\mathbf{T}^{1}$ & 13.70 & 13.70 & 9.93 & 9.93 & 3.45 & 3.43 \\
\hline & & $\mathbf{T}^{2}$ & 13.67 & 13.53 & 9.67 & 9.57 & 3.44 & 3.42 \\
\hline & & $\mathbf{T}^{3}$ & 12.90 & 13.07 & 9.37 & 9.43 & 3.41 & 3.41 \\
\hline & \multirow{3}{*}{$\mathbf{D}^{1}$} & $\mathbf{T}^{1}$ & 13.03 & 12.10 & 14.03 & 12.53 & 3.10 & 3.11 \\
\hline & & $\mathbf{T}^{2}$ & 11.73 & 12.03 & 13.63 & 12.23 & 3.06 & 3.05 \\
\hline & & $\mathbf{T}^{3}$ & 10.87 & 11.73 & 13.06 & 11.87 & 3.05 & 3.01 \\
\hline & \multirow{3}{*}{$\mathbf{D}^{2}$} & $\mathbf{T}^{1}$ & 11.93 & 12.43 & 13.60 & 12.37 & 3.10 & 3.10 \\
\hline & & $\mathbf{T}^{2}$ & 11.77 & 11.53 & 13.43 & 12.17 & 3.06 & 3.06 \\
\hline & & $\mathbf{T}^{3}$ & 11.77 & 10.90 & 12.87 & 11.70 & 3.05 & 3.03 \\
\hline & \multirow{3}{*}{$\mathbf{D}^{3}$} & $\mathbf{T}^{1}$ & 12.47 & 12.57 & 11.83 & 10.47 & 3.03 & 3.02 \\
\hline & & $\mathbf{T}^{2}$ & 11.60 & 11.23 & 11.47 & 10.23 & 3.02 & 3.00 \\
\hline & & $\mathbf{T}^{3}$ & 11.27 & 10.79 & 11.10 & 9.93 & 2.99 & 2.99 \\
\hline & \multirow{3}{*}{$\mathbf{D}^{1}$} & $\mathbf{T}^{1}$ & 11.67 & 11.33 & 14.37 & 13.20 & 2.76 & 2.76 \\
\hline & & $\mathbf{T}^{2}$ & 11.03 & 11.27 & 14.17 & 12.97 & 2.76 & 2.73 \\
\hline & & $\mathbf{T}^{3}$ & 10.90 & 11.13 & 13.43 & 12.20 & 2.70 & 2.61 \\
\hline & \multirow{3}{*}{$\mathbf{D}^{2}$} & $T^{1}$ & 11.53 & 11.17 & 13.90 & 12.47 & 2.79 & 2.76 \\
\hline & & $\mathbf{T}^{2}$ & 11.00 & 11.70 & 13.87 & 12.13 & 2.72 & 2.63 \\
\hline & & $\mathbf{T}^{3}$ & 10.93 & 10.67 & 13.13 & 11.83 & 2.59 & 2.60 \\
\hline & \multirow{3}{*}{$\mathbf{D}^{3}$} & $\mathbf{T}^{1}$ & 11.07 & 10.90 & 12.23 & 11.07 & 2.65 & 2.65 \\
\hline & & $\mathbf{T}^{2}$ & 10.63 & 10.77 & 11.73 & 10.50 & 2.64 & 2.62 \\
\hline & & $\mathbf{T}^{3}$ & 9.93 & 9.73 & 11.57 & 10.40 & 2.55 & 2.52 \\
\hline $\begin{array}{l}\text { L.S.D } \\
0.05\end{array}$ & \multicolumn{2}{|c|}{ IDT } & ns & ns & ns & $\mathrm{ns}$ & ns & ns \\
\hline
\end{tabular}

Table(4): The effect of irrigation intervals, defoliant type, and spraying date on lint percentage, plant yield and seed cotton yield, for Giza 92 variety in 2010 and 2011 seasons.

\begin{tabular}{|c|c|c|c|c|c|c|c|}
\hline \multicolumn{2}{|c|}{ Main effects } & \multicolumn{2}{|c|}{$\begin{array}{c}\text { Lint } \\
\text { Percentage \% }\end{array}$} & \multicolumn{2}{|c|}{$\begin{array}{c}\text { Plant } \\
\text { Yield(g.) } \\
\end{array}$} & \multicolumn{2}{|c|}{$\begin{array}{c}\text { Seed cotton } \\
\text { yield }(\mathbf{k} / \mathbf{f})\end{array}$} \\
\hline & & 2010 & 2011 & 2010 & 2011 & 2010 & 2011 \\
\hline \multirow{3}{*}{$\begin{array}{c}\text { Irrigation } \\
\text { intervals }\end{array}$} & $\mathbf{I}^{\mathbf{1}}$ & 35.46 & 35.30 & 32.36 & 31.99 & 10.93 & 10.99 \\
\hline & $\mathbf{I}^{2}$ & 31.58 & 31.00 & 29.75 & 28.61 & 10.03 & 9.80 \\
\hline & $\mathbf{I}^{3}$ & 29.75 & 28.45 & 28.98 & 28.70 & 8.09 & 8.45 \\
\hline L.S.D 0.05 & & 0.14 & 0.09 & 0.36 & 0.31 & 0.12 & 0.13 \\
\hline \multirow{3}{*}{ Defoliant } & $\mathbf{D}^{1}$ & 32.98 & 32.25 & 32.08 & 31.62 & 10.33 & 10.37 \\
\hline & $\mathbf{D}^{2}$ & 32.10 & 31.45 & 31.99 & 30.97 & 10.30 & 10.33 \\
\hline & $\mathbf{D}^{3}$ & 31.71 & 31.12 & 27.03 & 26.70 & 8.41 & 8.51 \\
\hline L.S.D 0.05 & & 0.15 & 0.05 & 0.51 & 0.53 & 0.20 & 0.19 \\
\hline \multirow{3}{*}{$\begin{array}{l}\text { Spraying } \\
\text { date }\end{array}$} & $\mathbf{T}^{\mathbf{1}}$ & 32.41 & 31.73 & 31.16 & 30.51 & 9.98 & 9.98 \\
\hline & $\mathbf{T}^{2}$ & 32.28 & 31.63 & 30.08 & 29.83 & 9.58 & 9.67 \\
\hline & $\mathbf{T}^{3}$ & 32.10 & 31.47 & 29.85 & 28.95 & 9.49 & 9.57 \\
\hline L.S.D 0.05 & & 0.11 & 0.05 & 0.53 & 0.53 & 0.20 & 0.20 \\
\hline
\end{tabular}


Table (5): Effects of the first order interactions between irrigation intervals, defoliant type, and spraying date on lint percentage, plant yield and seed cotton yield, for Giza 92 cotton variety in 2010 and 2011 seasons.

\begin{tabular}{|c|c|c|c|c|c|c|c|c|}
\hline \multicolumn{3}{|c|}{ Character } & \multicolumn{2}{|c|}{$\begin{array}{c}\text { Lint } \\
\text { Percentage } \%\end{array}$} & \multicolumn{2}{|c|}{$\begin{array}{c}\text { Plant } \\
\text { Yield }(\mathrm{g})\end{array}$} & \multicolumn{2}{|c|}{$\begin{array}{c}\text { Seed Cotton } \\
\text { Yield }(\mathbf{k} / \mathbf{f})\end{array}$} \\
\hline \multicolumn{3}{|c|}{ Treatment } & 2010 & 2011 & 2010 & 2011 & 2010 & 2011 \\
\hline \multirow{9}{*}{ 泀 } & & $\mathbf{D}^{1}$ & 35.71 & 35.62 & 33.84 & 33.41 & 11.49 & 11.53 \\
\hline & I 1 & $D^{2}$ & 35.38 & 35.21 & 33.60 & 33.16 & 11.40 & 11.44 \\
\hline & & $\mathbf{D}^{3}$ & 35.28 & 35.06 & 29.65 & 29.41 & 9.89 & 10.02 \\
\hline & & $\mathrm{D}^{1}$ & 32.52 & 31.48 & 31.57 & 30.89 & 10.73 & 10.48 \\
\hline & I2 & $D^{2}$ & 31.52 & 31.29 & 31.56 & 29.33 & 10.72 & 10.47 \\
\hline & & $\mathbf{D}^{3}$ & 30.70 & 30.48 & 26.13 & 25.61 & 8.66 & 8.43 \\
\hline & & $\mathbf{D}^{1}$ & 30.72 & 29.67 & 30.83 & 30.58 & 8.80 & 9.16 \\
\hline & J3 & $\mathbf{D}^{2}$ & 29.38 & 27.85 & 30.80 & 30.43 & 8.78 & 9.10 \\
\hline & & $\mathbf{D}^{3}$ & 29.16 & 27.83 & 25.31 & 25.09 & 6.69 & 7.07 \\
\hline \multirow{9}{*}{ 苞 } & & $\mathbf{T}^{\mathbf{1}}$ & 35.53 & 35.40 & 33.60 & 32.95 & 11.40 & 11.37 \\
\hline & I & $\mathbf{T}^{2}$ & 35.48 & 35.31 & 31.92 & 31.69 & 10.76 & 10.87 \\
\hline & $\mathbf{1}$ & $\mathbf{T}^{3}$ & 35.36 & 35.19 & 31.57 & 31.34 & 10.62 & 10.74 \\
\hline & & $\mathbf{T}^{1}$ & 31.71 & 31.23 & 30.34 & 29.40 & 10.26 & 9.97 \\
\hline & $\mathbf{I}^{2}$ & $\mathbf{T}^{2}$ & 31.61 & 31.09 & 29.53 & 29.22 & 9.95 & 9.75 \\
\hline & & $\mathbf{T}^{3}$ & 31.42 & 30.92 & 29.38 & 27.21 & 9.89 & 9.65 \\
\hline & & $\mathbf{T}^{\mathbf{1}}$ & 30.00 & 28.55 & 29.53 & 29.19 & 8.30 & 8.63 \\
\hline & $\mathbf{I}^{3}$ & $\mathbf{T}^{2}$ & 29.74 & 28.48 & 28.79 & 28.59 & 8.02 & 8.40 \\
\hline & & $\mathbf{T}^{3}$ & 29.52 & 28.31 & 28.62 & 28.32 & 7.95 & 8.30 \\
\hline \multirow{9}{*}{ 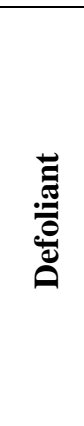 } & & $\mathbf{T}^{1}$ & 33.13 & 32.43 & 32.80 & 32.09 & 10.61 & 10.54 \\
\hline & $D^{1}$ & $\mathbf{T}^{2}$ & 33.08 & 32.30 & 31.81 & 31.49 & 10.24 & 10.33 \\
\hline & & $\mathbf{T}^{3}$ & 32.74 & 32.03 & 31.63 & 31.29 & 10.17 & 10.29 \\
\hline & & $\mathbf{T}^{\mathbf{1}}$ & 32.28 & 31.55 & 32.76 & 32.07 & 10.59 & 10.62 \\
\hline & $\mathbf{D}^{2}$ & $\mathbf{T}^{2}$ & 32.07 & 31.49 & 31.63 & 31.40 & 10.17 & 10.22 \\
\hline & & $\mathbf{T}^{3}$ & 31.94 & 31.31 & 31.57 & 29.46 & 10.14 & 10.16 \\
\hline & & $\mathbf{T}^{1}$ & 31.83 & 31.20 & 27.92 & 27.38 & 8.75 & 8.80 \\
\hline & $\mathbf{D}^{3}$ & $\mathbf{T}^{2}$ & 31.59 & 31.09 & 26.80 & 26.61 & 8.33 & 8.46 \\
\hline & & $\mathbf{T}^{3}$ & 31.62 & 31.06 & 26.37 & 26.12 & 8.16 & 8.25 \\
\hline \multirow{3}{*}{ ڤึ } & \multirow{3}{*}{\multicolumn{2}{|c|}{$\begin{array}{l}\text { ID } \\
\text { IT } \\
\text { DT }\end{array}$}} & 0.27 & 0.09 & 0.88 & ns & ns & 0.33 \\
\hline & & & ns & ns & ns & 0.91 & 0.35 & ns \\
\hline & & & 0.20 & 0.08 & ns & $\mathrm{ns}$ & ns & ns \\
\hline
\end{tabular}

effect of the interaction between irrigation interval and defoliant type in 2011 season, and the interaction between irrigation interval and defoliant application date in 2010 season. As for the effect of irrigation interval, the first irrigation treatment $\left(\mathrm{I}_{1}\right)$ resulted in the highest seed cotton yield $(10.93 \mathrm{k} / \mathrm{f}$ and $10.99 \mathrm{k} / \mathrm{f}$ in 2010 and 2011 seasons ,respectively). Similar results were obtained by Silvertooth and Galadima (2003) and Zaxos et al. (2012), Jill et al. (2006) and Cetin et al.(2011). Similar trend was shown by defoliant type, where "Dropp" gave the highest seed yield in both seasons. Application of the recommended dose of "Dropp" after 60\% of bolls are open provided the highest yield of $(9.98 \mathrm{k} / \mathrm{f}$ and 9.98 $\mathrm{k} / \mathrm{f}$ ) in 2010 and 2011 seasons, respectively. This yield increase may be due to the increased boll weight from early defoliation as mentioned above which is in harmony with Phipps et al. (2003) who found that delayed defoliation may increase boll rot or possible damage or loss of lint and fiber quality due to weathering. Yield can also be reduced, therefore defoliation decisions are a compromise between late season yield gains. The interaction between irrigation interval and defoliant type shows that applying the normal irrigation interval with the defoliant "Dropp" surpassed the other treatment in seed cotton yield in the first season $(11.53 \mathrm{k} / \mathrm{f})$. The interaction between irrigation interval and application date showed that the first irrigation and the application of $60 \%$ boll open gave the highest seed cotton yield (11.40kf) in 2010 season only. 
Table (6): Effects of the second order interaction between irrigation intervals, defoliant type and spraying date on lint percentage, plant yield $\mathbf{l}(\mathrm{g}$.)and seed cotton yield, for Giza 92 variety in 2010 and 2011 seasons

\begin{tabular}{|c|c|c|c|c|c|c|c|c|}
\hline \multirow{2}{*}{\multicolumn{3}{|c|}{$\begin{array}{l}\text { Character } \\
\text { Treatments } \\
\end{array}$}} & \multicolumn{2}{|c|}{$\begin{array}{c}\text { Lint } \\
\text { Percentage } \%\end{array}$} & \multicolumn{2}{|c|}{$\begin{array}{c}\text { Plant } \\
\text { Yield(g) }\end{array}$} & \multicolumn{2}{|c|}{$\begin{array}{c}\text { Seed cotton Yield } \\
(\mathbf{k} / \mathbf{f})\end{array}$} \\
\hline & & & 2010 & 2011 & 2010 & 2011 & 2010 & 2011 \\
\hline \multirow{27}{*}{ 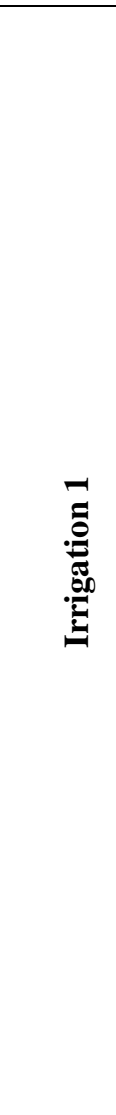 } & \multirow{3}{*}{$\mathbf{D}^{1}$} & $T^{1}$ & 35.80 & 35.77 & 35.00 & 34.03 & 11.93 & 11.76 \\
\hline & & $\mathbf{T}^{2}$ & 35.77 & 35.63 & 33.40 & 33.17 & 11.32 & 11.43 \\
\hline & & $\mathbf{T}^{3}$ & 35.57 & 35.47 & 33.13 & 33.03 & 11.22 & 11.38 \\
\hline & \multirow{3}{*}{$\mathbf{D}^{2}$} & $T^{1}$ & 35.47 & 35.30 & 35.00 & 34.33 & 11.93 & 11.88 \\
\hline & & $\mathbf{T}^{2}$ & 35.40 & 35.27 & 32.90 & 32.63 & 11.13 & 11.23 \\
\hline & & $\mathbf{T}^{\mathbf{3}}$ & 35.27 & 35.07 & 32.90 & 32.53 & 11.13 & 11.19 \\
\hline & \multirow{3}{*}{$\mathbf{D}^{\mathbf{3}}$} & $T^{1}$ & 35.33 & 35.13 & 30.80 & 30.50 & 10.33 & 10.46 \\
\hline & & $\mathbf{T}^{2}$ & 35.27 & 35.03 & 29.47 & 29.26 & 9.82 & 9.95 \\
\hline & & $\mathbf{T}^{3}$ & 35.23 & 35.00 & 28.67 & 28.47 & 9.52 & 9.65 \\
\hline & \multirow{3}{*}{$\mathbf{D}^{1}$} & $T^{1}$ & 32.63 & 31.63 & 31.90 & 31.13 & 10.85 & 10.49 \\
\hline & & $\mathbf{T}^{2}$ & 32.60 & 31.53 & 31.50 & 30.93 & 10.70 & 10.48 \\
\hline & & $\mathbf{T}^{\mathbf{3}}$ & 32.33 & 31.27 & 31.30 & 30.60 & 10.63 & 10.46 \\
\hline & \multirow{3}{*}{$\mathbf{D}^{2}$} & $\mathbf{T}^{\mathbf{1}}$ & 31.60 & 31.43 & 32.37 & 31.27 & 11.03 & 10.81 \\
\hline & & $\mathbf{T}^{2}$ & 31.60 & 31.33 & 31.17 & 31.20 & 10.57 & 10.36 \\
\hline & & $\mathbf{T}^{\mathbf{3}}$ & 31.37 & 31.10 & 31.13 & 25.53 & 10.56 & 10.23 \\
\hline & \multirow{3}{*}{$\mathbf{D}^{3}$} & $\mathbf{T}^{\mathbf{1}}$ & 30.90 & 30.63 & 26.76 & 25.80 & 8.90 & 8.60 \\
\hline & & $\mathbf{T}^{2}$ & 30.63 & 30.40 & 25.93 & 25.53 & 8.58 & 8.40 \\
\hline & & $\mathbf{T}^{3}$ & 30.57 & 30.40 & 25.70 & 25.50 & 8.49 & 8.28 \\
\hline & \multirow{3}{*}{$D^{1}$} & $\mathbf{T}^{\mathbf{1}}$ & 30.97 & 29.90 & 31.50 & 31.13 & 9.05 & 9.37 \\
\hline & & $\mathbf{T}^{2}$ & 30.87 & 29.73 & 30.53 & 30.37 & 8.68 & 9.08 \\
\hline & & $\mathbf{T}^{3}$ & 30.33 & 29.37 & 30.47 & 30.23 & 8.66 & 9.03 \\
\hline & \multirow{3}{*}{$D^{2}$} & $\mathbf{T}^{\mathbf{1}}$ & 29.77 & 27.91 & 30.90 & 30.60 & 8.82 & 9.17 \\
\hline & & $\mathbf{T}^{2}$ & 29.20 & 27.88 & 30.83 & 30.37 & 8.80 & 9.08 \\
\hline & & $\mathbf{T}^{3}$ & 29.17 & 27.75 & 30.67 & 30.33 & 8.73 & 9.07 \\
\hline & \multirow{3}{*}{$D^{3}$} & $\mathbf{T}^{\mathbf{1}}$ & 29.25 & 27.85 & 26.20 & 25.83 & 7.03 & 7.35 \\
\hline & & $\mathbf{T}^{2}$ & 29.17 & 27.83 & 25.00 & 25.03 & 6.58 & 7.05 \\
\hline & & $\mathbf{T}^{3}$ & 29.07 & 27.80 & 24.73 & 24.40 & 6.47 & 6.81 \\
\hline $\begin{array}{l}\text { L.S.D } \\
0.05\end{array}$ & \multicolumn{2}{|c|}{ IDT } & 0.34 & $\mathrm{~ns}$ & ns & ns & ns & ns \\
\hline
\end{tabular}

Table(7): The effect of irrigation intervals ,defoliant type, and spraying date on upper half mean length, fiber strength and micronaire value for Giza 92 cotton variety in 2010 and 2011 seasons.

\begin{tabular}{|c|c|c|c|c|c|c|c|}
\hline \multicolumn{2}{|c|}{ Main effects } & \multicolumn{2}{|c|}{ UHM(mm) } & \multicolumn{2}{|c|}{$\begin{array}{c}\text { Fiber strength } \\
\text { (g.tex) }\end{array}$} & \multicolumn{2}{|c|}{$\begin{array}{c}\text { Micronaire } \\
\text { value }\end{array}$} \\
\hline & & 2010 & 2011 & 2010 & 2011 & 2010 & 2011 \\
\hline \multirow{3}{*}{$\begin{array}{l}\text { Irrigation } \\
\text { intervals }\end{array}$} & $\mathbf{I}^{\mathbf{1}}$ & 34.71 & 34.56 & 48.73 & 48.80 & 3.87 & 3.81 \\
\hline & $\mathbf{I}^{2}$ & 32.90 & 31.97 & 46.02 & 45.04 & 3.25 & 3.08 \\
\hline & $\mathbf{I}^{3}$ & 32.18 & 30.79 & 44.94 & 44.60 & 3.12 & 3.07 \\
\hline L.S.D 0.05 & & 0.10 & 0.11 & 0.41 & 0.24 & 0.06 & 0.07 \\
\hline \multirow{3}{*}{ Defoliant } & $\mathbf{D}^{1}$ & 33.55 & 32.66 & 47.01 & 46.51 & 3.55 & 3.48 \\
\hline & $\mathrm{D}^{2}$ & 33.40 & 32.53 & 46.56 & 46.26 & 3.44 & 3.33 \\
\hline & $\mathbf{D}^{3}$ & 32.85 & 32.13 & 46.12 & 45.66 & 3.24 & 3.15 \\
\hline L.S.D 0.05 & & 0.07 & 0.12 & 0.19 & 0.19 & 0.06 & 0.08 \\
\hline \multirow{3}{*}{$\begin{array}{c}\text { Spraying } \\
\text { date }\end{array}$} & $\mathbf{T}^{\mathbf{1}}$ & 33.42 & 32.68 & 47.15 & 46.84 & 3.57 & 3.49 \\
\hline & $\mathbf{T}^{2}$ & 33.28 & 32.43 & 46.75 & 46.22 & 3.42 & 3.31 \\
\hline & $\mathbf{T}^{3}$ & 33.09 & 32.21 & 45.79 & 45.37 & 3.25 & 3.15 \\
\hline L.S.D 0.05 & & 0.08 & 0.09 & 0.28 & 0.18 & 0.05 & 0.05 \\
\hline
\end{tabular}




\subsubsection{Lint percentage}

Data in Tables $(4,5 \& 6)$, show that the effects of the main factors and the first order interactions on lint percentage were generally significant in both seasons except for the effects of the interaction between irrigation interval and time of application. The effect of the other interactions was significant in the first season only. Normal irrigation at 15 day intervals gave the highest lint percentage in both seasons (35.46\% and $35.30 \%$ ) ,respectively. The defoliant "Dropp" increased lint percentage compared with "Prep" defoliant in both seasons $(32.98 \%$ and $32.25 \%$ respectively), as indicated by Faircloth et al., 2004. With reference to defoliant spraying time, spraying after $60 \%$ of open bolls exceeded other application treatments in lint percentage $(32.41 \%$ and $31.73 \%$ ), respectively in both seasons,. According to the effect of the interaction between irrigation interval and defoliant type the highest lint percentages were $35.71 \%$ and $35.62 \%$ in both seasons. The interaction between defoliant type and spraying time increased the lint percentage ,. (33.13\% and $32.43 \%$ ) respectively in 2010 and 2011 seasons. Also, the effect of the interaction between irrigation interval, defoliant type and time of application increased lint percentage (35.80\%) in 2010 season.

\subsubsection{Fiber properties \\ 3.1.7. 1. Fiber length}

Data pertaining to fiber length $(\mathrm{mm})$ of Giza 92 variety under the applied treatments in the two experimental seasons are given in Tables $(7,8 \& 9)$. The results show that the effect of irrigation interval, defoliant type, defoliant application time and their interactions were significant in both seasons except for the interaction between defoliant type and application time in 2011 season only. Concerning the effect of irrigation treatments, normal irrigation $\left(\mathrm{I}_{1}\right)$ resulted in the highest fiber length (34.71 and $34.56 \mathrm{~mm}$ respectively) in both seasons,. In contrast, the lowest values (32.18 and $30.79 \mathrm{~mm})$ were obtained by the third irrigation treatment $\left(\mathrm{I}_{3}\right)$. In conclusion, fiber length decreased as the irrigation interval increased. These results are in line with those obtained by Silvertooth \& Galadima (2002), and Zaxos et al. (2012) while ( Jill et al (2006). , and Cetin et al.,2011) This may be due to the fact that cotton plants irrigated normally are characterized with strong vegetative growth. resulting in greater accumulation of dry matter, which enhances cotton fiber length. Regarding the effect of the defoliant type on fiber length, the defoliant "Dropp" surpassed the defoliant "Prep"
(33.55 and $32.66 \mathrm{~mm}$.) vs. (33.40and $32.53 \mathrm{~mm}$ ) in both seasons, respectively. These results are in agreement with Fromme et al. (2005) who concluded that the chemical defoliants such as "Dropp" had no significant effect on fiber length. The effect of the application date shows that spraying the defoliant after $60 \%$ of bolls are open enhances fiber length $(33.42$ and $32.68 \mathrm{~mm}$ in 2010 and 2011 seasons, respectively) as compared to the other treatments due to the decreased occurence of boll rot and damage by weather and insects. As for the effect of the interaction between irrigation treatments and defoliant type treatments, the data in Table (8) indicate that the maximum fiber length (34.83 and $34.76 \mathrm{~mm}$ ) was obtained from normal irrigation and using the defoliant "Dropp". Concerning the effect of the interaction between irrigation treatments and the defoliant application date, normal irrigation coupled with spraying defoliant when $60 \%$ bolls are open had a favorable influence on fiber length in both seasons ( 34.84 and $34.71 \mathrm{~mm}$ ). The interaction between defoliant type and defoliant application date showed that spraying "Dropp" defoliant at $60 \%$ open bolls gave the greatest value of fiber length $(32.85 \mathrm{~mm}$.) in 2011 season. The interaction between irrigation interval, defoliant type and defoliant application date showed that the greatest fiber length (34.90 and $34.83 \mathrm{~mm}$ ) was obtained under normal irrigation and spraying "Dropp" defoliant after 60 $\%$ of bolls are open in both 2010 and 2011 seasons. On the contrary, irrigation at four-week interval and spraying "Prep" defoliant after $80 \%$ of bolls are open decreased fiber length to 31.27 and $29.73 \mathrm{~mm}$ in 2010 and 2011 seasons, respectively.

\subsubsection{Fiber strength}

Results in Tables (7, 8 and 9) show that fiber strength $(\mathrm{g} / \mathrm{tex})$ was significantly affected by all the factors under the study and their interactions were significant in both seasons. Concerning the main factor (irrigation interval) the first irrigation treatment (two- week interval) gave the strongest fibers (48.73and $48.80 \mathrm{~g} / \mathrm{tex}$ ) for both seasons. These results are in harmony with (Zaxos et al., 2012). With reference to the second factor (defoliant type), "Dropp" defoliant surpassed "Prep" defoliant in fiber strength (47.01and $46.51 \mathrm{~g} / \mathrm{tex}$. in 2010 and 2011 seasons, respectively. These results are in agreement with Fromme et al. (2005) who concluded that chemical defoliants had no significant effect on fiber strength due to using "Droppd" as a 
Table (8):Effect of the first order interaction between irrigation intervals, defoliant type, and spraying date on upper half mean, strength and micronaire value for Giza 92 cotton variety in 2010 and 2011.

\begin{tabular}{|c|c|c|c|c|c|c|c|c|}
\hline \multirow{2}{*}{\multicolumn{3}{|c|}{$\begin{array}{l}\text { Character } \\
\text { Treatment }\end{array}$}} & \multicolumn{2}{|c|}{ UHM(mm) } & \multicolumn{2}{|c|}{$\begin{array}{l}\text { Fiber strength } \\
\text { (g.tex) }\end{array}$} & \multicolumn{2}{|c|}{$\begin{array}{c}\text { Micronaire } \\
\text { value }\end{array}$} \\
\hline & & & 2010 & 2011 & 2010 & 2011 & 2010 & 2011 \\
\hline \multirow{9}{*}{. } & & $\mathbf{D}^{1}$ & 34.83 & 34.76 & 49.19 & 49.12 & 3.96 & 3.93 \\
\hline & $\mathbf{I}^{1}$ & $\mathbf{D}^{2}$ & 34.74 & 34.47 & 48.67 & 49.11 & 3.93 & 3.83 \\
\hline & & $\mathbf{D}^{3}$ & 34.57 & 34.46 & 48.33 & 48.16 & 3.72 & 3.66 \\
\hline & & $\mathrm{D}^{1}$ & 33.29 & 32.07 & 46.70 & 45.63 & 3.40 & 3.23 \\
\hline & $\mathbf{I}^{2}$ & $\mathbf{D}^{2}$ & 32.92 & 31.99 & 46.16 & 45.13 & 3.26 & 3.08 \\
\hline & & $\mathbf{D}^{3}$ & 32.49 & 31.86 & 45.22 & 44.38 & 3.10 & 2.94 \\
\hline & & $\mathbf{D}^{1}$ & 32.53 & 31.17 & 45.16 & 44.81 & 3.30 & 3.02 \\
\hline & $\mathbf{I}^{3}$ & $\mathbf{D}^{2}$ & 32.51 & 31.15 & 44.87 & 44.54 & 3.14 & 3.08 \\
\hline & & $\mathbf{D}^{3}$ & 31.49 & 30.06 & 44.81 & 44.44 & 2.91 & 2.86 \\
\hline \multirow{9}{*}{ 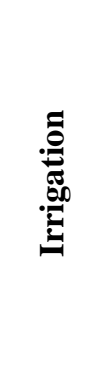 } & & $\mathbf{T}^{\mathbf{1}}$ & 34.84 & 34.71 & 49.33 & 49.63 & 3.97 & 3.95 \\
\hline & $\mathbf{I}^{1}$ & $\mathbf{T}^{2}$ & 34.70 & 34.53 & 48.93 & 48.81 & 3.83 & 3.75 \\
\hline & & $\mathbf{T}^{3}$ & 34.60 & 34.43 & 47.92 & 47.94 & 3.81 & 3.72 \\
\hline & & $\mathbf{T}^{\mathbf{1}}$ & 33.14 & 32.38 & 46.78 & 45.80 & 3.42 & 3.24 \\
\hline & $\mathbf{I}^{2}$ & $\mathbf{T}^{2}$ & 32.91 & 31.93 & 46.32 & 45.29 & 3.28 & 3.11 \\
\hline & & $\mathbf{T}^{3}$ & 32.65 & 31.61 & 44.97 & 44.06 & 3.06 & 2.90 \\
\hline & & $\mathbf{T}^{\mathbf{1}}$ & 32.28 & 30.97 & 45.36 & 45.11 & 3.32 & 3.29 \\
\hline & $\mathbf{I}^{3}$ & $\mathbf{T}^{2}$ & 32.24 & 30.83 & 45.00 & 44.57 & 3.14 & 3.08 \\
\hline & & $\mathbf{T}^{3}$ & 31.01 & 30.57 & 44.48 & 44.12 & 2.89 & 2.83 \\
\hline \multirow{9}{*}{ 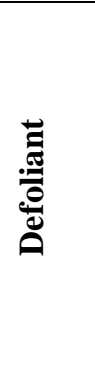 } & & $\mathbf{T}^{\mathbf{1}}$ & 33.65 & 32.85 & 47.37 & 46.91 & 3.59 & 3.57 \\
\hline & $\mathbf{D}^{1}$ & $\mathbf{T}^{2}$ & 33.57 & 32.72 & 47.03 & 46.49 & 3.58 & 3.45 \\
\hline & & $\mathbf{T}^{3}$ & 33.42 & 32.41 & 46.64 & 46.16 & 3.49 & 3.41 \\
\hline & & $\mathbf{T}^{\mathbf{1}}$ & 33.53 & 32.72 & 47.07 & 46.94 & 3.55 & 3.46 \\
\hline & $\mathbf{D}^{2}$ & $\mathbf{T}^{2}$ & 33.48 & 32.53 & 46.88 & 46.35 & 3.44 & 3.34 \\
\hline & & $\mathbf{T}^{3}$ & 33.19 & 32.36 & 45.73 & 45.49 & 3.34 & 3.19 \\
\hline & & $\mathbf{T}^{1}$ & 33.08 & 32.48 & 47.02 & 46.69 & 3.58 & 3.46 \\
\hline & $\mathbf{D}^{3}$ & $\mathbf{T}^{2}$ & 32.81 & 32.04 & 46.35 & 45.82 & 3.23 & 3.15 \\
\hline & & $\mathbf{T}^{3}$ & 32.66 & 31.86 & 45.00 & 44.47 & 2.92 & 2.86 \\
\hline \multirow{3}{*}{$\begin{array}{l}\text { L.S.D } \\
0.05\end{array}$} & \multirow{3}{*}{\multicolumn{2}{|c|}{$\begin{array}{l}\text { ID } \\
\text { IT } \\
\text { DT }\end{array}$}} & 0.13 & 0.20 & 0.33 & 0.34 & 0.14 & 0.13 \\
\hline & & & 0.13 & 0.15 & 0.48 & 0.31 & ns & ns \\
\hline & & & ns & 0.15 & 0.48 & 0.31 & 0.09 & 0.09 \\
\hline
\end{tabular}

defoliant. The defoliant spraying time showed that spraying after $60 \%$ of bolls open usually resulted in the maximum values of fiber strength (47.15 and 46.84g/tex in both seasons) .These results are in line with Snipes and Baskin, (1999) and Phipps et al., (2002). The effect of the interaction between irrigation intervals and defoliant type, showed that the interaction between the first irrigation treatment and "Dropp" defoliant gave the highest fiber strength (49.19 and $49.12 \mathrm{~g} / \mathrm{tex} . i n$ both seasons, respectively). As for the interaction between irrigation interval and the application time, the interaction between the first irrigation and the application of defoliant after $60 \%$ open bolls gave the highest fiber strength values (49.33 and 49.63(g/tex.) in both seasons). The second order interaction among the three factors (Table 9) showed that spraying Giza 92 variety with "Dropp" defoliant after $60 \%$ of bolls are open with normal irrigation (15 day intervals) increased fiber strength to 49.67 and $49.90 \mathrm{~g} / \mathrm{tex}$ in both seasons, respectively .

\subsubsection{Micronaire value}

Data presented in Tables (7, 8 and 9) clearly show that micronaire values for all the factors under study and their interactions were significant in both seasons, except for the interaction between irrigation interval and spraying time. Concerning irrigation interval, the first irrigation treatment (two- week interval) gave the highest micronaire values (3.87 and 3.81) in both seasons. These results are in harmony with (Zaxos et al., 2012). With reference to the secondary factor (defoliant type) "Dropp" defoliant surpassed"Prep" defoliant in micronaire values (3.55 and 3.48) in 2010 and 2011 seasons, respectively. With respect to defoliant spraying time, spraying after $60 \%$ of bolls open usually exhibited the highest micronaire values (3.57 and 3.49) in both seasons, 
Table (9): Effect of the second order interactions between irrigation intervals, defoliant type, and spraying date on upper half mean, fiber strength and micronaire value for Giza 92 cotton variety in 2010 and 2011 seasons.

\begin{tabular}{|c|c|c|c|c|c|c|c|c|}
\hline \multirow{2}{*}{\multicolumn{3}{|c|}{$\begin{array}{l}\text { Character } \\
\text { Treatment }\end{array}$}} & \multicolumn{2}{|c|}{ UHM(mm) } & \multicolumn{2}{|c|}{$\begin{array}{c}\text { Fiber strength } \\
(\text { g.tex })\end{array}$} & \multicolumn{2}{|c|}{$\begin{array}{c}\text { Micronaire } \\
\text { value }\end{array}$} \\
\hline & & & 2010 & 2011 & 2010 & 2011 & 2010 & 2011 \\
\hline \multirow{27}{*}{ 골 } & \multirow{3}{*}{$\mathbf{D}^{1}$} & $\mathbf{T}^{\mathbf{1}}$ & 34.90 & 34.83 & 49.67 & 49.90 & 3.97 & 3.97 \\
\hline & & $\mathbf{T}^{2}$ & 34.90 & 34.83 & 49.13 & 48.77 & 3.97 & 3.93 \\
\hline & & $\mathbf{T}^{3}$ & 34.70 & 34.60 & 48.77 & 48.70 & 3.93 & 3.90 \\
\hline & \multirow{3}{*}{$\mathbf{D}^{2}$} & $\mathbf{T}^{\mathbf{1}}$ & 34.80 & 34.53 & 49.00 & 49.67 & 3.97 & 3.90 \\
\hline & & $\mathbf{T}^{2}$ & 34.73 & 34.43 & 49.00 & 49.00 & 3.93 & 3.83 \\
\hline & & $\mathbf{T}^{3}$ & 34.70 & 34.43 & 48.00 & 48.67 & 3.90 & 3.77 \\
\hline & \multirow{3}{*}{$\mathbf{D}^{3}$} & $\mathbf{T}^{\mathbf{1}}$ & 34.83 & 34.77 & 49.33 & 49.33 & 3.97 & 3.97 \\
\hline & & $\mathbf{T}^{2}$ & 34.47 & 34.33 & 48.67 & 48.67 & 3.60 & 3.50 \\
\hline & & $\mathbf{T}^{3}$ & 34.40 & 34.27 & 47.00 & 46.47 & 3.60 & 3.50 \\
\hline & \multirow{3}{*}{$\mathbf{D}^{1}$} & $\mathbf{T}^{\mathbf{1}}$ & 33.47 & 32.43 & 47.03 & 45.70 & 3.47 & 3.33 \\
\hline & & $\mathbf{T}^{2}$ & 33.27 & 32.07 & 46.57 & 45.63 & 3.43 & 3.23 \\
\hline & & $\mathbf{T}^{3}$ & 33.13 & 31.70 & 46.50 & 45.57 & 3.30 & 3.13 \\
\hline & \multirow{3}{*}{$\mathbf{D}^{2}$} & $\mathbf{T}^{\mathbf{1}}$ & 33.17 & 32.37 & 46.90 & 46.03 & 3.37 & 3.20 \\
\hline & & $\mathbf{T}^{2}$ & 33.07 & 32.06 & 46.83 & 45.66 & 3.30 & 3.13 \\
\hline & & $\mathbf{T}^{3}$ & 32.53 & 31.57 & 44.73 & 43.70 & 3.10 & 2.90 \\
\hline & \multirow{3}{*}{$\mathbf{D}^{3}$} & $\mathbf{T}^{\mathbf{1}}$ & 32.77 & 32.33 & 46.40 & 45.67 & 3.43 & 3.20 \\
\hline & & $\mathbf{T}^{2}$ & 32.40 & 31.67 & 45.57 & 44.57 & 3.10 & 2.97 \\
\hline & & $\mathbf{T}^{3}$ & 32.30 & 31.57 & 43.70 & 42.90 & 2.77 & 2.67 \\
\hline & \multirow{3}{*}{$\mathbf{D}^{1}$} & $\mathbf{T}^{\mathbf{1}}$ & 32.63 & 31.30 & 45.40 & 45.13 & 3.33 & 3.40 \\
\hline & & $\mathbf{T}^{2}$ & 32.63 & 31.27 & 45.40 & 45.07 & 3.33 & 3.20 \\
\hline & & $\mathbf{T}^{3}$ & 32.33 & 30.43 & 44.67 & 44.23 & 3.23 & 3.20 \\
\hline & \multirow{3}{*}{$\mathbf{D}^{2}$} & $\mathbf{T}^{\mathbf{1}}$ & 32.57 & 31.27 & 45.33 & 45.07 & 3.30 & 3.27 \\
\hline & & $\mathbf{T}^{2}$ & 32.53 & 31.10 & 44.80 & 44.40 & 3.10 & 3.07 \\
\hline & & $\mathbf{T}^{3}$ & 32.43 & 31.07 & 44.47 & 44.10 & 3.03 & 2.90 \\
\hline & \multirow{3}{*}{$\mathbf{D}^{3}$} & $\mathbf{T}^{1}$ & 31.63 & 30.33 & 45.33 & 45.07 & 3.33 & 3.20 \\
\hline & & $\mathbf{T}^{2}$ & 31.57 & 30.13 & 44.80 & 44.23 & 3.00 & 2.97 \\
\hline & & $\mathbf{T}^{3}$ & 31.27 & 29.73 & 44.30 & 44.03 & 2.40 & 2.40 \\
\hline L.S.D 0.05 & \multicolumn{2}{|c|}{ IDT } & 0.24 & 0.26 & 0.84 & 0.61 & 0.15 & 0.15 \\
\hline
\end{tabular}

which agrees with Snipes and Baskin (1999).The effect of the interaction between irrigation intervals and defoliant types, data in Table (8) indicate that the interaction between the first irrigation treatment and "Dropp" defoliant gave the highest micronaire values $(3.96$ and 3,93) in both seasons. The interaction between irrigation interval and application time, as well as the interaction between the first irrigation and the application of defoliant after $60 \%$ open bolls gave the highest micronaire values (3.97 and 3.95) in 2010 and 2011seasons, respectively. The second order interaction among the three factors showed that spraying Giza 92 variety with the "Dropp" defoliant after $60 \%$ of bolls open with normal irrigation ( 15 day intervals ) surpassed the other interactions in micronaire values (3.97and 3.97). It is worth mentioning that micronaire values incorporate both fineness and maturity. Fiber fineness is a genetic trait influenced by genotype, while maturity is affected by environment.
Accordingly the variation between the treatments expresses maturity.

It could be concluded applying "Dropp" defoliant after $60 \%$ of bolls are open, coupled with normal irrigation gave the highest values of cotton agronomic and yield characters, in addition to the best fiber quality.

\section{REFERENCES}

ASTM (1986). American standards for testing materials(ASTM),D -3818, and D - 4605.US.A.

Barker G.L., McClendon R.W., Colwick R.F. and Jones J.W. (1987). Relationship between cotton lint color and weather exposure. Transactions of the ASAE.22(3): 470-474.

Cetin K., Karademir E., Ekinci R. and Berekatoğlu.K. (2011). Yield and fiber quality properties of cotton (Gossypium hirsutum L.) under water stress and non-stress conditions. African Journal of Biotechnology.Vol.10(59), pp. 12575-12583, 3 . 
